\title{
On the Validity of the Capital Asset Pricing Model (CAPM)
}

\author{
M. J. Alhabeeb ${ }^{1}$ \\ ${ }^{1}$ University of Massachusetts Amherst, USA \\ Correspondence: M. J. Alhabeeb, Professor of University of Massachusetts Amherst, USA. E-mail: \\ mja@resecon.umass.edu
}

Received: September 30, 2020

Accepted: October 30, 2020 Online Published: November 9, 2020

doi:10.5539/ijms.v12n4p1

URL: https://doi.org/10.5539/ijms.v12n4p1

\begin{abstract}
This study exposes the meaning and role of the Capital Asset Pricing Model (CAPM) and lays out the key elements that make it work. It shows the model's theoretical strength and examines its applicability and validity as a technical tool to measure the expected return to the investment in stock, along with assessing the market risk associated with that investment.
\end{abstract}

Keywords: CAPM, financial Beta, SLM, risk and return, asset pricing, stock return

\section{Introduction}

Investment in market securities has been around since the early 17th century, but little has been known about the extent of risk involved within the financial market, despite the general awareness of the mere association of risk and investment. Perold (2004) claimed that not until the mid 1940s and 1950s, rigorous theories of investor risk preferences and financial decision-making under uncertainty started to be published. Examples of those pioneering publications were the work of Neumann and Morgenstern (1944) and Savage (1954). Almost a decade later, Markowitz (1952) pioneered with his Modern Portfolio Theory (MPT) in which he posited that ordinary risk-averse investors can build a financial portfolio to either maximize their assets' return, given an accepted level of market risk, or to accept a certain level of return that would minimize the risk involved in that investment (Markowitz, 1952). By 1958, Modigliani and Miller laid out the foundation of a valuation theory for the firm and its shares under the conditions of uncertainty. They studied the cost of capital in corporations and devised an operational definition of the cost of equity capital and how it can be used as a basis for the decision making of rational investment. They noted that the firm's capital structure has virtually no effect on the firm value or its shares. In the same paper they recognized that there has been no explanation whatsoever for what determines the level of risk involved in the financial market and how and when it might change in response to changes in other variables. In the same year, 1958, Tobin published his paper on risk and liquidity preference. He explained why investors would prefer to keep their financial portfolios well diversified in terms of both contents: liquid assets and securities.

At the start of the 1960s, and building on Markowitz $(1952,1959)$ and Modern Portfolio Theory, as well as on Tobin (1958), many economists, working independently tried to devise methods to help estimate the expected return on equity capital versus its cost in terms of market risk (Treynor, 1961, 1962; Sharpe, 1964; Lintner, 1965; Mossin, 1966; Black, 1972). The most recognized study was Sharpe (1964), to which the capital asset pricing model (CAPM) was credited as the main model, while other variations were recognized by other authors. Black (1972) came up with another, qualitatively different model called zero-beta CAPM or Black CAPM in which he assumed the non-existence of the risk-free assets. It is noteworthy to mention here that the 1990 Nobel Prize in financial economics was given jointly to Sharpe, Markowitz, and Miller for their groundbreaking work in this field.

Prior to the economic crisis of the mid 2000, $65 \%$ of American households had some sort of investment in the stock market. This percentage dropped to $55 \%$ after the recession during that time. In general, young people tend to understand and accept more risk in their investment than older people. Based on the labeled generations, the percent of population which are willing to take more risk and are prepared to accept its consequences on their investment returns are: $45 \%$ for generation X, $36 \%$ for the millennials, $31 \%$ for the baby boomers, and $18 \%$ for the greatest generation (Statita.com, 2019). Investment professionals and portfolio managers for individuals and firms have been relying on the Capital Asset Pricing Model, along with other fundamental principles and 
technical methods of securities analysis to make decisions on the expected return on investment and account for the anticipated risk.

Since its inception, CAPM never seized to be more controversial in terms of its applicability. Despite its popularity and wide use, it remains a concept that tend to ignite rigorous academic debate, especially on the empirical phase of the model. Tsong-Yue and Stohs (2015) confirmed that the empirical verification of CAPM has been extensively discussed throughout the financial economic literature. This study exposes the meaning and role of the Capital Asset Pricing Model and lays out the key elements that make it work. It examines its validity as a technical model and shows its theoretical strength and empirical downfalls.

\section{Concept and Assumptions}

The Capital Asset Pricing Model (CAPM) is considered, by most critics, the first coherently consistent model to describe the relationship between the return on investment in stocks and the risk involved in that investment, plus the cost of equity capital. It takes into consideration the sensitivity to market's non-diversifiable risk where the utility function would take a specific form in which variance would measure the risk level, and the risk-free rate of return would account for the Time Value of Money. CAPM has been widely used as a technical tool for pricing risky securities and provide a rough estimate of their expected return versus its systematic risk brought using an outlay of capital.

The model is set up based on several assumptions:

- Markets of securities are competitive and efficient, where all related information are directly, universally, and quickly distributed to all investors, at the same time.

- All assets in the market are fixed and given. They are liquid and highly divisible.

- All investors are considered:

o Rational, risk-averse, and homogeneous in their expectations. While they are diversified across a range of investments, they seek to maximize their economic utility out of their investment ventures.

- Price takers with no influence on market prices.

o Borrowers or lenders with limitless amounts of money for the risk-free rate of interest.

$\circ$ Traders with no transaction fees, nor with taxes.

A major component in this model is the financial beta $(\beta)$ which we should address first before we get into the details of the model.

\section{The Financial Beta $(\beta)$}

Beta $(\beta)$ is a mathematical tool to measure the systematic undiversifiable market risk. It is, in this sense, an index of the extent to which a security return moves in response to the changes in the overall market. This would make it as a measure of the securities volatility in relation to an average security represented by the state of the market. Market return is an aggregate measure of the return of all traded securities in the market at a specific time. Beta value can be positive or negative. Generally, it ranges between -2.5 to 2.5 . The value of 1.00 denotes the full impact of market risk. Any individual security with a beta of 1.00 indicates that the return pattern of that security moves up and down perfectly with the market return. The value of zero refers to a total independence from the market impact. A value of more than 1.00 reveals that the security is as more volatile as the average security in the market.

A negative value says that the asset return pattern moves in opposite direction to the market. The following table shows beta coefficients of selected American Companies estimated at some point in time. The estimation changes for the same company from time to time. 
Table 1. Beta Estimates for selected American companies

\begin{tabular}{ll}
\hline Company & Beta \\
\hline AOL & 2.46 \\
Dell & 2.23 \\
Microsoft & 1.82 \\
Texas Instrument & 1.75 \\
Intel & 1.70 \\
GE & 1.16 \\
GM & 1.10 \\
Colgate-Palmolive & 1.03 \\
Family Dollar Store & .99 \\
K-Mart & .98 \\
ATT & .98 \\
McGraw Hill & .81 \\
Gillette & .76 \\
MY Times & .71 \\
JC Penny & .52 \\
Johnson \& Johnson & .49 \\
Campbell & .41 \\
Exxon & .36 \\
\hline
\end{tabular}

Mathematically, Beta is obtained by dividing the covariance between the individual security return $\left(\mathrm{k}_{\mathrm{i}}\right)$ and the market return $\left(\mathrm{k}_{\mathrm{m}}\right)$ by the variance of market return $(\mathrm{km})$.

$$
\beta=\frac{\operatorname{COV}\left(\mathrm{k}_{\mathrm{i}}, \mathrm{k}_{\mathrm{m}}\right)}{\operatorname{Var}\left(\mathrm{k}_{\mathrm{m}}\right)}
$$

In this sense, Beta is a concept of correlation to assess how one security return is correlated with the rest in the market. From another perspective, Beta measures the percentage change in one security return as it responds to the changes in the external market return. It can be, therefore, interpreted as the financial elasticity of the change in each asset relative to market change. Accordingly, Beta becomes the slope of the regression line between the changes in market return and the corresponding response of the asset return. In the following Figure 1, the changes in market return are tracked down on the horizontal axis and the responses to them by a given security are tracked down on the vertical axis. The result would be the regression line.

$\mathrm{Y}=\alpha+\beta \mathrm{x}+\mathrm{e}$, where its slope would be standing for Beta and calculated by dividing the change in the vertical axis over the change in the horizontal axis.

$$
\text { Beta }=\beta=\frac{\Delta Y}{\Delta X}
$$




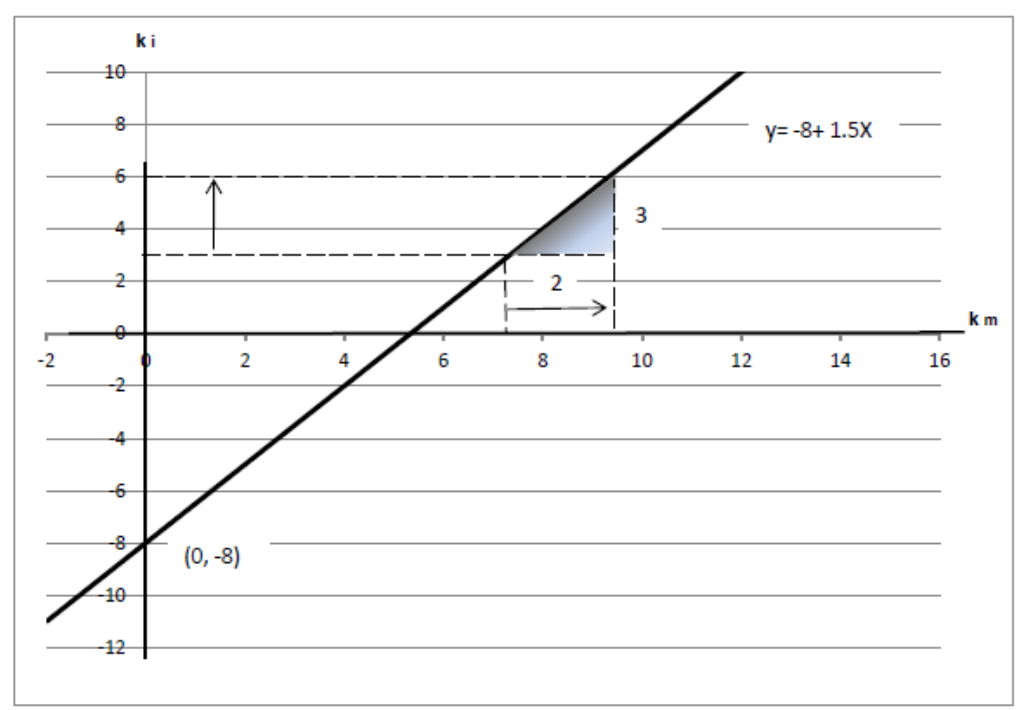

Figure 1. Beta as the slope of the regression line of the change in market return

If, for example, we track down the change in the market rate when it increases from 7.3 to 9.3 , the linear equation line of $y=-8+1.5 x$ would allow the return of the asset $k_{i}$ to increase from 3 to 6 . Therefore, we can obtain the slope of the line

$$
\text { Slope }=\frac{\Delta Y}{\Delta X}=\frac{6-3}{9.3-7.3}=\frac{3}{2}=1.5
$$

which is the same as the value of $\beta$ in the equation of the line. This says that the asset rate of return follows the market return more with it but even more robustly. Its volatility as one and a half as the volatility of the market return. For example, if the market rate increases by $5 \%$, this asset's rate would increase by $7.5 \%$. We can also calculate Beta value by the formula method given ealier. As an example, we can calculate Beta for x-corporation given 10 periodic rates of return $\left(\mathrm{k}_{\mathrm{i}}^{\mathrm{m}}\right)$ and market rates for the same period $\left(\mathrm{k}_{\mathrm{i}}^{\mathrm{m}}\right)$. In the following table, we calculate the expected return of both as the averages $\left(\mathrm{k}_{\mathrm{e}}^{\mathrm{x}}\right)$ and $\left(\mathrm{k}_{\mathrm{e}}^{\mathrm{m}}\right)$, and we proceed to calculate the covariance between the two sets of rates and the variance of the market. Beta would be calculated by dividing the covariance by the market variance.

$$
\begin{aligned}
\operatorname{cov}(\mathrm{x}, \mathrm{m}) & =\frac{\sum_{\mathrm{i}=1}^{10}\left(\mathrm{k}_{\mathrm{i}}^{\mathrm{x}}-\mathrm{k}_{\mathrm{e}}^{\mathrm{x}}\right)\left(\mathrm{k}_{\mathrm{i}}^{\mathrm{m}}-\mathrm{k}_{\mathrm{e}}^{\mathrm{m}}\right)}{\mathrm{N}} \\
\operatorname{cov}(\mathrm{x}, \mathrm{m}) & =\frac{.04773}{10}=.0048 \\
\operatorname{var}(\mathrm{m}) & =\frac{\sum_{\mathrm{i}=1}^{10}\left(\mathrm{k}_{\mathrm{i}}^{\mathrm{m}}-\mathrm{k}_{\mathrm{e}}^{\mathrm{m}}\right)^{2}}{\mathrm{~N}} \\
\operatorname{var}(\mathrm{m}) & =\frac{.0348}{10}=.0035
\end{aligned}
$$




$$
\begin{gathered}
\beta_{x}=\frac{\operatorname{cov}(x, m)}{\operatorname{var}(m)} \\
\beta_{x}=\frac{.0048}{.0035}=1.37
\end{gathered}
$$

Note that $\beta_{\mathrm{x}}$ is just the beta for Asset X. A portfolio beta would be weighted average of betas for all individual assets within the portfolio:

$$
\beta_{\mathrm{p}}=\sum_{\mathrm{i}=1}^{\mathrm{n}} \beta_{\mathrm{i}} \mathrm{w}_{\mathrm{i}}
$$

where $\beta_{\mathrm{p}}$ is the portfolio beta, $\beta_{\mathrm{i}}$ is the beta for any individual asset within the portfolio, $\mathrm{w}_{\mathrm{i}}$ is the proportion of asset $\mathrm{i}$ out of the entire portfolio that contains n-assets.

Table 2. Rates of return for $\mathrm{x}$-corporation and the market for 10 periods

\begin{tabular}{lllllllll}
\hline \multicolumn{7}{l}{ x-corporation } & \multicolumn{7}{l}{ Market } \\
\hline & $\mathrm{K}_{\mathrm{i}}^{\mathrm{x}}$ & $\mathrm{K}_{\mathrm{e}}^{\mathrm{x}}$ & $\left(\mathrm{K}_{\mathrm{i}}^{\mathrm{x}} \mathrm{K}_{\mathrm{e}}^{\mathrm{x}}\right)$ & $\mathrm{K}_{\mathrm{i}}^{\mathrm{m}}$ & $\mathrm{K}_{\mathrm{e}}^{\mathrm{m}}$ & $\left(\mathrm{K}_{\mathrm{i}}^{\mathrm{m}} \mathrm{K}_{\mathrm{e}}^{\mathrm{m}}\right)$ & $\left(\mathrm{K}_{\mathrm{i}}^{\mathrm{m}} \mathrm{K}_{\mathrm{e}}^{\mathrm{m}}\right)^{2}$ & $\left(\mathrm{~K}_{\mathrm{i}}^{\mathrm{x}} \mathrm{K}_{\mathrm{e}}^{\mathrm{x}}\right)\left(\mathrm{K}_{\mathrm{i}}^{\mathrm{m}} \mathrm{K}_{\mathrm{e}}^{\mathrm{m}}\right)$ \\
\hline 1 & -.06 & .105 & -.165 & .027 & .082 & -.055 & .003 & .0091 \\
2 & .27 & .105 & .165 & .095 & .082 & .013 & .00017 & .0021 \\
3 & .065 & .105 & -.04 & .038 & .082 & -.044 & .0019 & .0018 \\
4 & .13 & .105 & .025 & .055 & .082 & -.027 & .00073 & -.00067 \\
5 & .055 & .105 & -.05 & -.017 & .082 & -.099 & .0098 & .0049 \\
6 & .28 & .105 & .175 & .176 & .082 & .094 & .0088 & .0164 \\
7 & -.045 & .105 & -.15 & .119 & .082 & .037 & .0014 & -.0055 \\
8 & .03 & .105 & -.075 & .128 & .082 & .046 & .0021 & -.0034 \\
9 & .35 & .105 & .245 & .156 & .082 & .074 & .0055 & .0181 \\
10 & -.025 & .105 & -.13 & .044 & .082 & -.038 & .0014 & .0049 \\
& & & & & & & .0348 & .04773 \\
\hline
\end{tabular}

\section{The CAPM Equation}

Now we know what Beta is, we can write the central equation of the Capital Asset Pricing Model where Beta becomes an essential factor to calculate the required rate of return on any asset $\left(\mathrm{k}_{\mathrm{i}}\right)$ given the asset Beta $\left(\beta_{\mathrm{i}}\right)$, the market's required rate of return $\left(\mathrm{k}_{\mathrm{m}}\right)$, and the riskless rate of return, which is traditionally the rate of return on the U.S. Treasury bond $\left(\mathrm{R}_{\mathrm{f}}\right)$ :

$$
\mathrm{k}_{\mathrm{i}}=\mathrm{R}_{\mathrm{f}}+\beta_{\mathrm{i}}\left[\mathrm{k}_{\mathrm{m}}-\mathrm{R}_{\mathrm{f}}\right]
$$

This model means that the required rate of return for any asset would be obtained by adding the risk-free rate of return to the market risk premium, given that this premium is:

1) representing the difference between the required rate of return and the risk-free rate of return, $\left[k_{m}-R_{f}\right]$

2) adjusted to that asset's index of risk by being multiplied by beta:

$$
\beta_{\mathrm{i}}\left[\mathrm{k}_{\mathrm{m}}-\mathrm{R}_{\mathrm{f}}\right]
$$

Accordingly, we can obtain the required rate of return for Y-corporation that has a beta of 1.85, given that the return on the market portfolio of assets is $12 \%$ and the risk-free rate is $6.5 \%$ ?

$$
\begin{aligned}
\mathrm{k}_{\mathrm{i}} & =\mathrm{R}_{\mathrm{f}}+\beta_{\mathrm{i}}\left[\mathrm{k}_{\mathrm{m}}-\mathrm{R}_{\mathrm{f}}\right] \\
& =.065+1.85[.12-.065] \\
& =16.67 \%
\end{aligned}
$$

So, the market risk premium is $5.5 \%(0.055=0.12-0.065)$, and it went to a little more than $10 \%$ when it was 
adjusted to the asset's index of risk, beta of 1.85 . When the result of the adjustment was added to the risk-free rate of $6.5 \%$, we got the corp required rate of $16.67 \%$.

Algebraically, we can obtain any of $\beta_{\mathrm{i}}, \mathrm{R}_{\mathrm{f}}$, and $\mathrm{k}_{\mathrm{m}}$ if the other variables in the equation are available.

- Finding Beta:

$$
\begin{gathered}
\mathrm{k}_{\mathrm{i}}=\mathrm{R}_{\mathrm{f}}+\beta_{\mathrm{i}}\left[\mathrm{k}_{\mathrm{m}}-\mathrm{R}_{\mathrm{f}}\right] \\
\mathrm{k}_{\mathrm{i}}-\mathrm{R}_{\mathrm{f}}=\beta_{\mathrm{i}}\left[\mathrm{k}_{\mathrm{m}}-\mathrm{R}_{\mathrm{f}}\right] \\
\beta_{\mathrm{i}}=\frac{\mathrm{k}_{\mathrm{i}}-\mathrm{R}_{\mathrm{f}}}{\mathrm{k}_{\mathrm{m}}-\mathrm{R}_{\mathrm{f}}} \\
\beta_{\mathrm{i}}=\frac{.1667-.065}{.12-.065}=1.85
\end{gathered}
$$

- Finding the Free-Risk of Return $\left(\mathrm{R}_{\mathrm{f}}\right)$ :

$$
\begin{gathered}
\mathrm{k}_{\mathrm{i}}=\mathrm{R}_{\mathrm{f}}+\beta_{\mathrm{i}}\left[\mathrm{k}_{\mathrm{m}}-\mathrm{R}_{\mathrm{f}}\right] \\
\mathrm{k}_{\mathrm{i}}=\mathrm{R}_{\mathrm{f}}-\beta_{\mathrm{i}} \mathrm{R}_{\mathrm{f}}+\beta_{\mathrm{i}} \mathrm{k}_{\mathrm{m}} \\
\mathrm{k}_{\mathrm{i}}-\beta_{\mathrm{i}} \mathrm{k}_{\mathrm{m}}=\mathrm{R}_{\mathrm{f}}\left(1-\beta_{\mathrm{i}}\right) \\
\mathrm{R}_{\mathrm{f}}=\frac{\mathrm{k}_{\mathrm{i}}-\beta_{\mathrm{i}} \mathrm{k}_{\mathrm{m}}}{1-\beta_{\mathrm{i}}} \\
\mathrm{R}_{\mathrm{f}}=\frac{.1667-(1.85)(.12)}{1-1.85} \\
\mathrm{R}_{\mathrm{f}}=\frac{-.0553}{-.85}=.065
\end{gathered}
$$

- Finding the Market Rate of Return $\left(\mathrm{k}_{\mathrm{m}}\right)$

$$
\begin{gathered}
\mathrm{k}_{\mathrm{i}}=\mathrm{R}_{\mathrm{f}}+\beta_{\mathrm{i}}\left[\mathrm{k}_{\mathrm{m}}-\mathrm{R}_{\mathrm{f}}\right] \\
\mathrm{k}_{\mathrm{i}}=\mathrm{R}_{\mathrm{f}}+\beta_{\mathrm{i}} \mathrm{k}_{\mathrm{m}}-\beta_{\mathrm{i}} \mathrm{R}_{\mathrm{f}} \\
\mathrm{k}_{\mathrm{i}}+\mathrm{R}_{\mathrm{f}}\left(\beta_{\mathrm{i}}-1\right)=\beta_{\mathrm{i}} \mathrm{k}_{\mathrm{m}} \\
\mathrm{k}_{\mathrm{m}}=\frac{\mathrm{k}_{\mathrm{i}}+\mathrm{R}_{\mathrm{f}}\left(\beta_{\mathrm{i}}-1\right)}{\beta_{\mathrm{i}}} \\
\mathrm{k}_{\mathrm{m}}=\frac{.1667+.065(1.85-1)}{1.85} \\
\mathrm{k}_{\mathrm{m}}=.12
\end{gathered}
$$

\section{The Security Market Line (SML)}

When we graph the CAPM equation, we get a straight line with a positive slope equal to beta (1.85). This line is called the security market line (SML). From the last example we have all the points we need to draw the SML for this example. As shown in the following Figure 2, the level of risk, as measured by Beta, is on the horizontal axis, and the required rates of return are on the vertical axis. The risk-free rate of $6.5 \%$ is associated with zero beta, the market rate of $12 \%$ is associated with beta value of 1.00 , and the return $\mathrm{k}_{\mathrm{i}}$ of $16.67 \%$ is associated with a beta of 1.85. The vertical line BD represents the market risk premium which is obtained as (BE-DE) standing for $\left[\mathrm{k}_{\mathrm{m}}-\mathrm{R}_{\mathrm{f}}\right]$ in the equation. All assets that have betas higher than 1.00 would have a risk premium higher than the market risk premium. Our beta is 1.85 which makes the risk premium much higher than the market risk premium as it is depicted by the vertical line CE which is $(\mathrm{CF}-\mathrm{EF})=16.67-6.5=10.17$. Similarly, all assets that have betas less than 1.00 will have risk premiums less than the market risk premium. An example would be Firm $\mathrm{S}$ with a beta of .5. The risk premium for this firm would be represented by the line GH which is (GI-HI), and it is lower than the market risk premium. 




Figure 2. Level of risk and the required rates of return

The slope of SML stands for the degree of risk aversion. Steeper SML would reflect higher degree of risk aversion, and flatter SML would reflect lower degree of risk aversion in the economy. Also, the steeper the SML, the higher the risk premium and the higher the required rate of return on the risky assets with higher Betas.

- SML Shift by Inflation:

The risk-free rate of return $\left(\mathrm{R}_{\mathrm{f}}\right)$ is considered the price of money to a riskless borrower. It is, therefore, affected by inflation like any other price. In fact, it includes a built-in component designed to absorb the impact of inflation. This component is called the inflation premium (IP) which is to protect the investor's purchasing power from declining as the prices rise. The second component is the real core $\left(\mathrm{k}^{0}\right)$ that is inflation free.

$$
\mathrm{R}_{\mathrm{f}}=\mathrm{k}^{0}+\mathrm{IP}
$$

Let's assume that the risk-free rate of the last example, which is $6.5 \%$, is in fact a combination of the real rate $\mathrm{k}^{0}$, which is $2.5 \%$, and the inflation premium $4 \%$.

Since the SML originates from the $\mathrm{R}_{\mathrm{f}}$ point, any increase in inflation would lead to and increase to the IP component and to the $\mathrm{R}_{\mathrm{f}}$, and it would cause the point of SML origin to go up shifting the entire line up. The following Figure 3 shows how the SML shifts to a higher position $\left(\mathrm{SML}_{2}\right)$ originating from $8 \%$ rate if the inflation rises by 1.5 points from $4 \%$ to $5.5 \%$. 


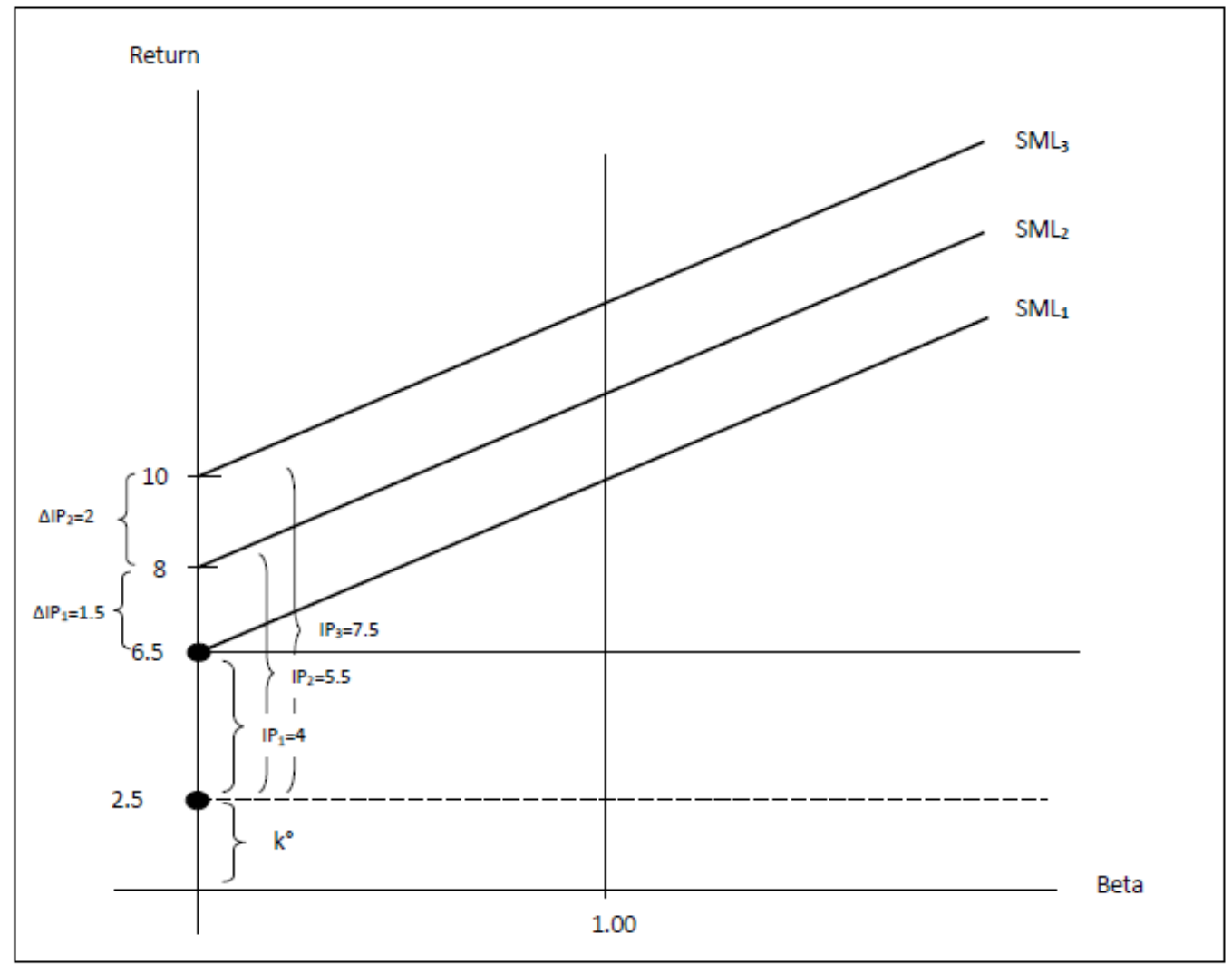

Figure 3. SML shifts according to inflation rates

$$
\begin{aligned}
\mathrm{R}_{\mathrm{f}}^{1} & =\mathrm{k}^{0}+\mathrm{IP}^{1} \\
& =2.5+4=6.5 \\
\mathrm{R}_{\mathrm{f}}^{2} & =\mathrm{k}^{0}+\mathrm{IP}_{2} \\
& =2.5+5.5=8.00
\end{aligned}
$$

and if inflation continues to rise, say to 7.5 , the $\mathrm{SML}$ shifts again to $\mathrm{SML}_{3}$ originating from

$$
\begin{aligned}
\mathrm{R}_{\mathrm{f}} & =10 . \\
\mathrm{R}_{\mathrm{f}}^{3} & =\mathrm{k}^{0}+\mathrm{IP}_{3} \\
& =2.5+7.5=10.0
\end{aligned}
$$

\section{SML and Risk Aversion}

The slope of the security market line (SML) represents how much risk aversion investors are usually exhibiting. The line, therefore, would swing up and down to reflect the change in investor's risk aversion. The slope would be equal to zero and the SML would be horizontal at the risk-free level of return $\left(\mathrm{R}_{\mathrm{f}}\right)$, and there would be no risk premium to the point that even risky assets would sell at the risk-free level of return. As the risk aversion starts to rise and the risk premium starts to grow, the SML would pivot at the $\mathrm{R}_{\mathrm{f}}$ point and its other end starts to rise according to how much risk premium there is. From that point, the line would continue to swing up. The following Figure 4 shows that when risk aversion rises, the market risk premium (MRP) would rise, in this example, from $4 \%$ to $9 \%$ (vertical $\mathrm{FG}$ to $\mathrm{EG}$ ), and consequently the market required rate $\left(\mathrm{k}_{\mathrm{m}}\right)$ would jump from $10 \%$ to $15 \%$ (vertical FK to EK), and our risky asset return $\left(\mathrm{k}_{\mathrm{i}}\right)$ of the 1.75 beta would be up from $13 \%$ to $21.75 \%$. This asset risk premium (RAP) would shoot from $7 \%$ to $15.75 \%$ (vertical CB to DB). 


$$
\begin{aligned}
\mathrm{k}_{\mathrm{i}}^{1} & =\mathrm{R}_{\mathrm{f}}+\beta_{\mathrm{i}}\left[\mathrm{k}_{\mathrm{m}}^{1}-\mathrm{R}_{\mathrm{f}}\right] \\
& =.06+1.75[.10-.06] \\
& =.06+.07 \\
& =.13
\end{aligned}
$$

where

$$
\begin{aligned}
\mathrm{k}_{\mathrm{i}}^{2} & =\mathrm{R}_{\mathrm{f}}+\beta_{\mathrm{i}}\left[\mathrm{k}_{\mathrm{m}}^{2}-\mathrm{R}_{\mathrm{f}}\right] \\
& =.06+1.75[.15-.06] \\
& =.06+.1575 \\
& =.2175
\end{aligned}
$$

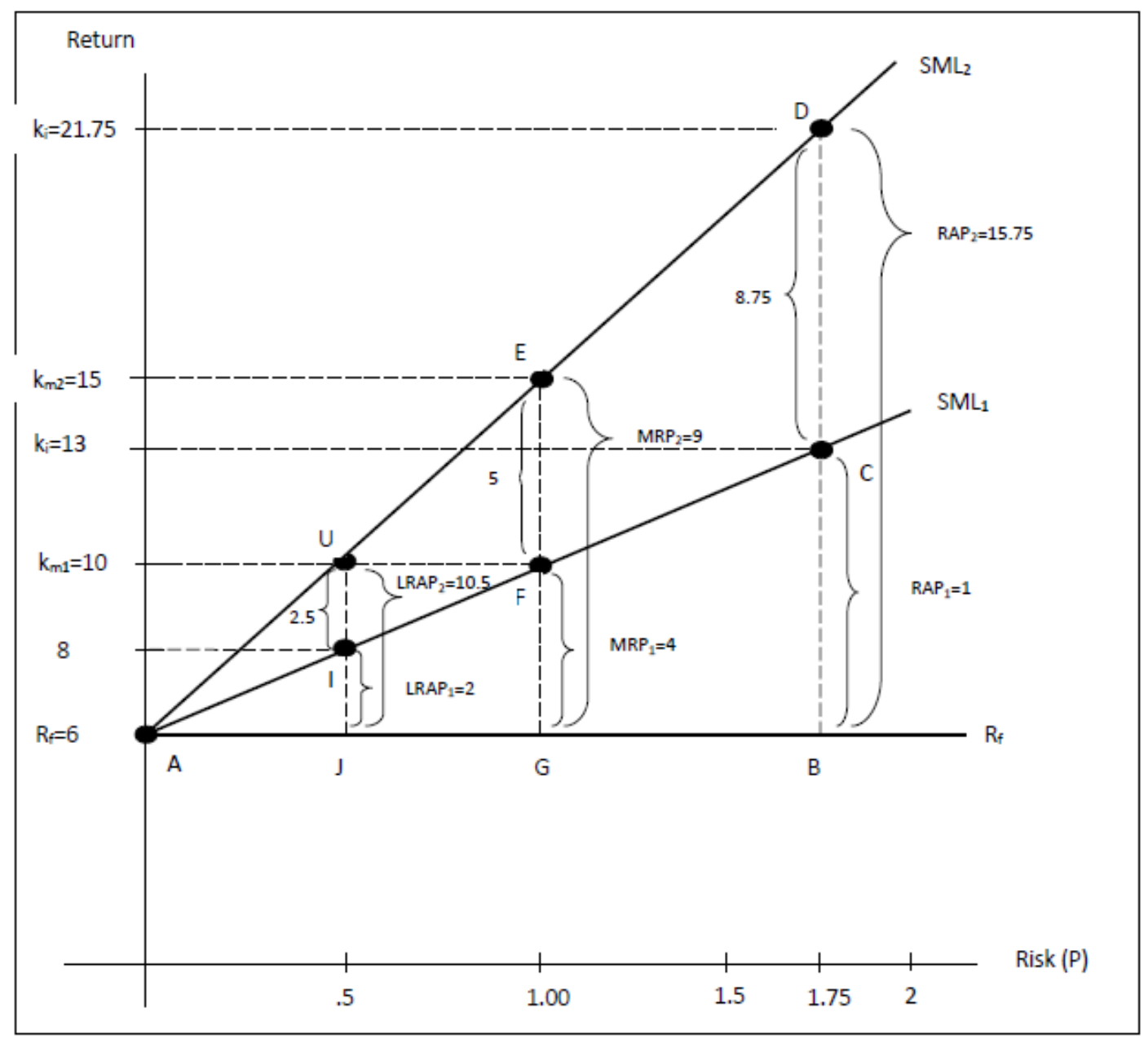

Figure 4. Risk aversion and market risk premium

where $1.75[.10-.06]=7 \%$ and $1.75[.15-.06]=15.75 \%$ are the risky asset's premiums during the change. This change would result in increasing the slope of the line and making it steeper. $\mathrm{SML}_{1}$ would swing up to $\mathrm{SML}_{2}$. The impact of the change in risk aversion level would be more pronounced on assets that are riskier with higher beta as compared to less risky assets that have betas less than 1.00. This is shown on the increase in the required rate of return between the two types of assets for the risky asset with 1.75 beta, the required rate of return increased by $8.75 \%$ (from $13 \%$ to $21.75 \%$ ), while the required rate of return for the asset of .5 beta rose by $2.5 \%$ (from $8 \%$ to $10.5 \%$ ). This means that such a risky asset of 1.75 beta faced an increase in the required return three 
times and a half more than what the less risky asset of .5 beta faced as an increase in its required return.

The last word about the slope of SML is important to emphasize. The SML slope is not equal to beta as it may be guessed by looking at the equation of the model.

$$
\mathrm{k}_{\mathrm{i}}=\mathrm{R}_{\mathrm{f}}+\beta_{\mathrm{i}}\left[\mathrm{k}_{\mathrm{m}}-\mathrm{R}_{\mathrm{f}}\right]
$$

Beta, as we have seen before, is equal to the slope of the regression line that describes the response of the return of a certain asset to the change in the market return. Let us consider the difference among three assets as they respond to a certain change in the market return. Let us assume that the market return at some point is $8 \%$ and it goes up to $12 \%$. That is an increase of $50 \%$. Let us also assume that our three assets $\mathrm{X}, \mathrm{Y}$, and $\mathrm{Z}$, all have $8 \%$ rates, and they respond to such a change in the market return by the following manner:

Asset X: Return increases by the same percentage as the market, $50 \%$. Its return of $8 \%$ goes up to $12 \%$.

Asset Y: Return increases by $100 \%$. It goes up from $8 \%$ to $16 \%$.

Asset Z: Return increases by $25 \%$. It goes from $8 \%$ to $10 \%$.

Asset $X$ would have a $45^{\circ}$ line going through the original point. Its slope is equal to 1 because the change in the asset return is the same as the change in the market return:

$$
\begin{aligned}
\text { slope }_{\mathrm{x}} & =\frac{\text { Rise }}{\text { Run }}=\frac{\Delta \text { asset return }}{\Delta \text { market return }} \\
& =\frac{12-8}{12-8}=1=\text { Beta }
\end{aligned}
$$

The line equation would be:

$$
\begin{gathered}
\mathrm{Y}=\mathrm{a}+\mathrm{b}_{\mathrm{x}} \\
\mathrm{Y}=0+(1)(\mathrm{x}) \\
\mathrm{Y}=\mathrm{x}
\end{gathered}
$$

Asset $\mathrm{Y}$ would have a line with a slope of 2, an $\mathrm{x}$-intercept at 4, and y-intercept at -8 :

$$
\text { slope }_{\mathrm{y}}=\frac{16-8}{12-8}=\frac{8}{4}=2
$$

The line equation would be:

$$
\mathrm{Y}=8+2_{\mathrm{x}}
$$

Asset $\mathrm{Z}$ would have a line with a slope of .5, and a y-intercept of 4 , and $\mathrm{x}=$ intercept of -8 :

$$
\text { slope }_{\mathrm{z}}=\frac{10-8}{12-8}=\frac{2}{4}=\frac{1}{2}
$$

The line equation would be:

$$
\mathrm{Y}=4+.5_{\mathrm{x}}
$$

Since all these three equations are linear equations of regression lines, Beta can be directly read off the equation as it corresponds to b-value in the standard format of the linear equation:

$$
\mathrm{Y}=\mathrm{a}+\mathrm{b}_{\mathrm{x}}
$$




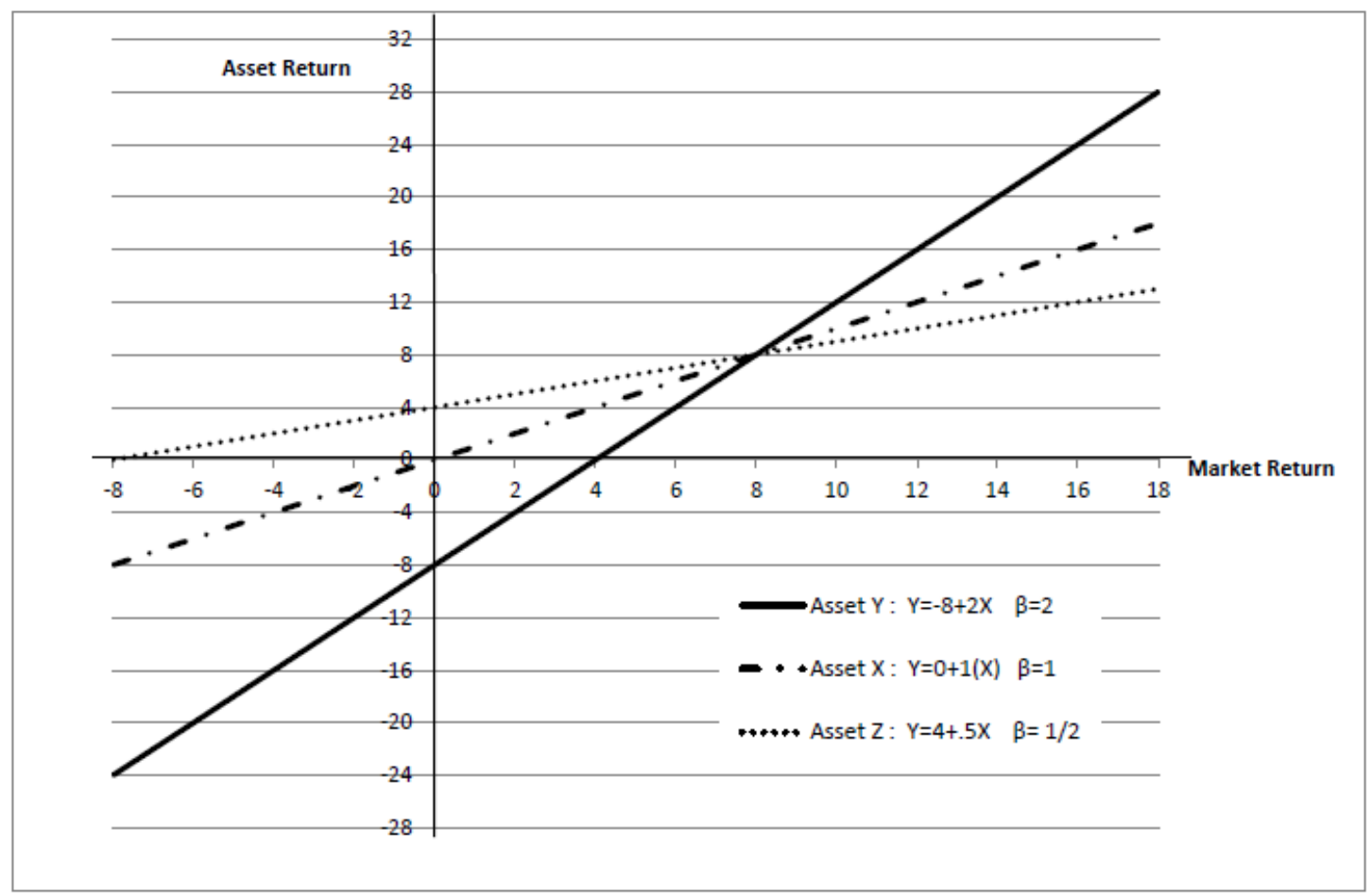

Figure 5. Asset return and market return thru three assets $\mathrm{X}, \mathrm{Y}, \mathrm{Z}$ with different betas

\section{Discussion}

A fundamental issue for any investor is the health and stability of their investment, and the impact of market risk on the return of that investment. This would warrant the need for a good estimation of the expected return under any potential risk. Most financial critics agree that the Capital Asset Pricing Model (CAPM) has been a valuable theoretical contribution to financial economics literature. Particularly for being: 1) a simple technique of calculation, 2) an effective tool to provide, at least, a rough estimate of the expected return, and 3) a reasonable determinant for the worth and appropriateness of a specific stock. Perold (2004) stated that CAPM "is an elegant theory with profound implications for asset pricing and investors' behavior". Fama and French (2004) agreed that CAPM is a "theoretical tour de force", and that it "offers powerful and intuitively pleasing predictions about how to measure risk and the relation between expected return and risk". However, the model is not perfect! There has been some doubt on its applicability and usefulness in real life. Fama and French (2004) continue to add that "unfortunately, the empirical record of the model is poor! Poor enough to invalidate the way it is used in applications. The empirical problems may reflect theoretical failings - the result of many simplifying assumptions. But they may also be caused by difficulties in implementing valid tests of the model". Perold (2004) is a little more tolerant in his criticism of how useful CAPM is! He hinted that while the model's usefulness is impeded by its idealized assumptions, it can still be considered in: 1) whether the real-world asset prices can conform to the predictions of the model, 2) the model's ability to predict future investor behavior, and 3) serving as a benchmark for understanding the capital market phenomena.

It is obvious that most of the criticism focus on the model's ability to be applied, and its usefulness in the real world. It is, therefore, safe to say that the doubt seems to be directed towards the validity of the model. Validity of a model refers to the state of cogency, i.e., being scientifically acceptable, having the ability to be logically and factually sound, convincing, and persuasive. Also being accurate in showing and measuring what it is intended to measure in the real world. Validity is all about showing how closely the results of the empirical work correspond to the structure of the theoretical model: properties, characteristics, relations, variations, and algorithms. In this respect, and according to most authors in this field, CAPM's validity was constantly in question. Tsong-Yue and Stohs (2015) said it bluntly, that CAPM cannot serve the purposes originally intended for it, and they declared that the model is dead! They explained that the model counts on the assumption that the expected rate of return depends on beta, while in reality, the opposite of this presumed relationship occurs, when beta depends on the expected rate of return for an asset. Therefore, they concluded that the model is beset with serious endogeniety problem and could also have an additional problem of circularity. Endogeniety reveals 
significant difficulties in obtaining reliable beta and cost of capital. Circularity of the model seems to pose an obstacle that appears insurmountable. Using logic and mathematics, the authors claimed that they algebraically proved that CAPM "is not empirically legitimate model to price assets".

Earlier, Fama and French (1996) confessed that the idea of "beta, as the sole variable explaining the return on stock is dead". In their later work of 2004, they declared that CAPM "has never been an empirical success". They explained that the major problem with the applicability of CAPM is the simplifying assumptions and the difficulties in using the market portfolio to test the model". In his empirical investigation of CAPM's applicability, Dayala (2012) found what he described as "possible irrationality and circularity of the model, which cast a shadow on the validity of the CAPM framework". His results supported the findings of an earlier study by Roll (1977).

\section{Conclusion}

Two of the most significant determinants of the price and stability of financial securities are risk and return, and how they affect each other. While financial returns directly express the performance of securities towards gain, risk stands for the chance of loss through expressing the variability of returns. This has been a fundamental reason for why most financial decision makers are risk averse. However, the ability and willingness to take higher risks is associated with the potentials to earn high returns. It was discussed that the only relevant risk is the non-diversifiable because the diversifiable risk can be greatly reduced and even eliminated by a sensible diversification of assets. In this context, the Capital Asset Pricing Model (CAPM) was explained and beta as risk measure was highlighted, theoretically and practically. Also, the concept of the Security Market Line (SML) was clarified and illustrated as it responds to inflation and risk aversion. CAPM was assessed theoretically and empirically. Literature showed that although the Model was theoretically a big success, it failed to match that success, empirically.

\section{References}

Black, F. (1972). Capital Market Equilibrium with Restricted Borrowing. Journal of Business, 45(3), 444-454. https://doi.org/10.1086/295472

Black, F., Michael, C. J., \& Myron, S. (1972). The Capital Asset Pricing Model: Some Empirical Tests. In C. J. Michael (Ed.), Studies in the Theory of Capital Markets (pp. 79-121). New York: Praeger.

Dayala, R. (2012). The Capital Asset Pricing Model. Business Valuation Review, 31(1), 23-34. https://doi.org/10.5791/BVR-D-12-00001.1

Fama, E. F., \& James, D. M. (1973). Risk, Return, and Equilibrium: Empirical Tests. Journal of Political Economy, 81(3), 607-636. https://doi.org/10.1086/260061

Fama, E. F., \& Kenneth, R. F. (1992). The Cross-Section of Expected Stock Returns. Journal of Finance, 47(2), 427-465. https://doi.org/10.1111/j.1540-6261.1992.tb04398.x

Fama, E. F., \& Kenneth, R. F. (1993). Common Risk Factors in the Returns on Stocks and Bonds. Journal of Financial Economics, 33(1), 3-56. https://doi.org/10.1016/0304-405X(93)90023-5

Fama, E. F., \& Kenneth, R. F. (2004). The Capital Asset Pricing Model: Theory and Evidence. Journal of Economic Perspectives, 18(3), 25-46. https://doi.org/10.1257/0895330042162430

Kenton, W. (2020). CAPM. Retrieved from http://www.Investopedia.com

Lintner, J. (1965a). The Valuation of Risk Assets and the Selection of Risky Investments in Stock Portfolios and Capital Budgets. Review of Economics and Statistics, 47(1), 13-37. https://doi.org/10.2307/1924119

Lintner, J. (1965b). Security Prices, Risk and Maximal Gains from Diversification. Journal of Finance, 20 , 587-615. https://doi.org/10.1111/j.1540-6261.1965.tb02930.x

Markowitz, H. (1952). Portfolio Selection. Journal of Finance, 7(1), 77-99. https://doi.org/10.2307/2975974

Markowitz, H. (1959). Portfolio Selection: Efficient Diversification of Investments. Cowles Foundation Monograph No. 16. New York: John Wiley \& Sons, Inc.

Merton, R. C. (1973). An Intertemporal Capital Asset Pricing Model. Econometrica, 41(5), 867-887. https://doi.org/10.2307/1913811

Merton, R. C. (1987). A Simple Model of Capital Market Equilibrium with Incomplete Information. Journal of Finance, 42, 483-510. https://doi.org/10.1111/j.1540-6261.1987.tb04565.x

Miller, M., \& Myron, S. (1972). Rates of Return in Relation to Risk: A Reexamination of Some Recent Findings. 
In C. J. Michael (Ed.), Studies in the Theory of Capital Markets (pp. 47-78). New York: Praeger.

Modigliani, F., \& Merton, H. M. (1958). The Cost of Capital, Corporation Finance, and the Theory of Investment. American Economic Review, 48(3), 261-297.

Mossin, J. (1966). Equilibrium in a Capital Asset Market. Econometrica, 35, $768-783$. https://doi.org/10.2307/1910098

Mullins, D. W. (1982). Does the Capital Asset Pricing Model Work? Harvard Business Review, 4-23.

Perold, A. (2004). The Capital Asset Pricing Model. Journal of Economic Perspectives, 18(3), 3-24. https://doi.org/10.1257/0895330042162340

Roll, R. (1977). A Critique of the Asset Pricing Theory's Tests' Part I: On Past and Potential Testability of the Theory. Journal of Financial Economics, 4(2), 129-176. https://doi.org/10.1016/0304-405X(77)90009-5

Sharpe, W. F. (1964). Capital Asset Prices: A Theory of Market Equilibrium under Conditions of Risk. Journal of Finance, 19(3), 425-442. https://doi.org/10.2307/2977928

Tobin, J. (1958). Liquidity Preference as Behavior Toward Risk. Review of Economic Studies, 25(2), 65-86. https://doi.org/10.2307/2296205

Treynor, J. L. (1962). Toward a Theory of Market Value of Risky Assets. Unpublished manuscript. In A. K. Robert (Ed.), Asset Pricing and Portfolio Performance (1999, pp. 15-22). London: Risk Books.

Tsong-Yue, L., \& Mark, H. S. (2015). Yes, CAPM is Dead. International Journal of Business, 20(2), $144-158$.

Von Neumann, J. L., \& Oskar, M. (1944). Theory of Games and Economic Behavior. Princeton, N.J.: Princeton University Press.

\section{Copyrights}

Copyright for this article is retained by the author, with first publication rights granted to the journal.

This is an open-access article distributed under the terms and conditions of the Creative Commons Attribution license (http://creativecommons.org/licenses/by/4.0/). 